\title{
'For the English to see' or effective change? How supply chains are shaped by laws and regulations, and what that means for the exposure of modern slavery
}

\section{SILVIA MARINA PINHEIRO, CAROLINE EMBERSON and ALEXANDER TRAUTRIMS}

Abstract: Global supply chains cross and connect judicial systems, providing regulatory and legal frameworks in which supply chains operate. This article investigates the impact and implementation of modern slavery laws and the broader legal framework surrounding Brazilian-UK beef and timber supply chains towards their modern slavery exposure in connection with their supply-chain characteristics. The article outlines the current challenges presented by modern slavery, labour exploitation, and human rights implementation to supply-chain management and explains the origins and application of current legal frameworks in which these supply chains operate. The heterogeneity of the two sectors allows the extraction of variations in supply-chain characteristics such as buyer-supplier relationships, responsible sourcing, supply-chain compliance, and the availability and accessibility of sales markets and supply options. These supply-chain characteristics are then connected to the legal frameworks and to current business practices to discuss their effect on modern slavery risks and exposure.

Keywords: Modern slavery, responsible sourcing, supply chain compliance, labour exploitation, human rights implementation.

\section{INTRODUCTION}

'Para Inglês Ver-For the English to see' is a phrase in Brazilian Portuguese that stems from the abolition of the transatlantic slave trade. Brazil had agreed to abolish the slave trade as a concession for Britain's support of its independence from Portugal. Brazil had no intention of enforcing legislation against the slave trade, but regulations were established to lend the appearance of the government's commitment to eradicate slavery. 
More recently, in what has been described as the fourth wave of the abolitionist movement (Choi-Fitzpatrick 2015), a range of legislative approaches have been enacted to eradicate modern slavery, largely by targetting trade and business supply chains. While slavery has been outlawed globally in national legal systems, the degree to which these regulatory frameworks are implemented effectively or have been established to give the impression of governmental efforts to end slavery is questionable.

The United Kingdom's Modern Slavery Act 2015 (MSA) requires commercial organisations with a turnover of more than $£ 36$ million to produce an annual modern slavery statement and the act's guidance notes specify they ought to 'disclose what activity they are undertaking to eliminate slavery and trafficking from their supply chains and their own business'. Although the Modern Slavery Act is a piece of domestic UK legislation, contemporary supply chains are by nature global and the legislation hence extends into activities, including non-UK businesses, which provide goods and services in the United Kingdom. The extraterritorial reach of the legislation aims to eliminate modern slavery from global supply chains. It should be noted that these supply chains are, however, not only covered by UK legislation but also by a myriad of hard-law and soft-law instruments which encompass anti-slavery policies and practices.

While the MSA adopts a generic interpretation of the term 'supply chain', this paper explores how the legislation is implemented in specific supply chains, and uses a supply-chain management perspective to identify which supply-chain characteristics and dynamics influence the implementation.

\section{MODERN SLAVERY CHALLENGES IN SUPPLY-CHAIN MANAGEMENT}

The term 'supply chain' is often used to describe the operations of a focal firm in a single supply chain. However, in reality, such companies operate within a complex supply-chain network, where individual firms are part of multiple supply chains with varying levels of complexity and globally interconnected flows of products, money, and information. Whilst modern slavery is not a new phenomenon, the concept is a new challenge to supply-chain managers. The variation of supply chains means the managerial challenge to eradicate modern slavery from supply chains also varies strongly between them (Gold et al. 2015).

In supply-chain management, modern slavery is often treated alongside sustainability and corporate social responsibility (CSR). Sustainable sourcing is seen as an insurance-based CSR approach: that is, a cost to prevent a negative impact for the firm. However, in the case of modern slavery and related sustainability issues, it is difficult to ascertain the reasons for share price performance. At best we must rely on anecdotal evidence (Kim et al. 2019). Nevertheless, while identifying modern slavery 
in supply chains can be a challenging and laborious task, the issue is often researched from a corporate risk-management and compliance perspective (Hofmann et al. 2018).

Supply chains vary in their risk or exposure to modern slavery. As a management practice, modern slavery follows a commercial logic of exploitation (Crane 2013), with many entrepreneurial elements. Paradoxical tensions often exist between social sustainability and profitability within buying firms (Xiao et al. 2019) that make a return on investment for slavery-preventing measures or anti-slavery interventions unlikely in many corporate and even public sector supply chains (Emberson \& Trautrims 2019, New 2015). Instead, one can often identify a first-mover disadvantage, which results from the costs of supplier development as well as from higher production costs. These costs run against the commercial logic and internal incentivisation of profit maximisation and cost reduction in buying organisations.

Responsible or ethical sourcing can, in some instances, even produce negative consequences and cause split in the markets, by dividing up supply chains that focus purely on socially conscious consumers who are willing to pay a premium for responsibly sourced products (Guo et al. 2015). The concept of ethically conscious consumers exercising sufficient pressure to shift businesses to responsible sourcing can be assumed to be limited to brand-exposed businesses and even this is of limited impact (Guo et al. 2015). Particularly in cost-driven commodity supply chains, market dynamics may constrain an industry-wide implementation of responsible sourcing practices.

Most procurement decisions in supply chains occur between businesses whereeven when sustainable procurement is taken seriously - modern slavery is only one of many sustainability considerations in a buying decision. In a procurement decision the criteria of supplier selection are usually weighted relative to their importance. Empirical work has shown that practitioners tend to reduce the importance of a particular issue in their supplier selection process if it is already covered by strong legislation which mitigates risk of that issue occurring in a supplier (Pishchulov et al. 2019). The responsibility for policing supply chains may therefore be a useful tool to fill a gap left by an absent or insufficient state actor.

Businesses by contrast are much more limited in their capabilities and responses to address a sustainability topic than functioning state bodies. Supplier audits and certifications are common business tools to police supply chains, but their effectiveness in addressing a sustainability topic is increasingly viewed sceptically by practitioners and researchers (LeBaron et al. 2017). The MSA's reporting requirements that follow the logic of businesses policing their supply chains is insufficiently covered by state actors.

Even when businesses are committed to the elimination of modern slavery within their supply chains, the identification and monitoring of all their suppliers and sub-tier 
suppliers are near-impossible tasks in global supply networks. The commercial relationship in supply chains usually does not stretch further than one tier. Where the commercial need for an extended supply chain visibility and management stretches to sub-tier suppliers, it is mainly for quality management and production planning. Applying extended supply-chain visibility and management to the topic of modern slavery would - beyond the resources needed at the focal firm-also require active collaboration and higher levels of trust from the sub-tier suppliers.

In their supply-chain management approaches, most businesses will naturally focus on their larger, strategic, suppliers which are commercially the most important to them, whereas most of the modern slavery risk may be in peripheral, hidden, and informal actors in the supply chain (New 2015) or in areas where modern slavery is structurally embedded in the business model and culturally accepted (Chesney et al. 2019). It is, therefore, hard to imagine that businesses can prevent modern slavery in their supply chains effectively without a functioning judicial state infrastructure operating at the same time.

To demonstrate the significance of effective legal systems and regulatory frameworks in preventing modern slavery in business and supply-chain operations, the follow section explains the history of anti-slavery law developments in Brazil and the United Kingdom, and the variations in their legal concepts of slavery, and discusses how anti-slavery provisions are implemented and applied in Brazil.

\section{HISTORICAL DEVELOPMENTS OF BRAZILIAN AND BRITISH ANTI-SLAVERY LAWS}

Brazil and Caribbean colonies in the 18th and 19th centuries were slave societies where labour was defined by slavery. Their entire social structure was rooted in slavery, with 25 per cent to 50 per cent of the total population in slavery. The enslavement and trafficking of people from West Africa - particularly to Brazil and Cuba-continued in the late 1830s with more than 300,000 victims within a single decade (Welsh 2009).

Brazilian anti-slavery laws are based on the experience of two centuries of legal slavery in Brazil. The long history of the social structure as a slave society also adds a cultural component to explain why, despite slavery being recognised as a crime in Brazil, more than a thousand victims of slavery are still identified every year.

Brazilian anti-slavery laws date from the middle of the 20th century when slavery was included in the Penal Code. The term 'conditions analogous to that of a slave' in the Brazilian Penal Code is linked to Brazil's history and memories within civil society (Gomes 2008). Some authors also point to the importance of transnational judicial activism that arose after the first Brazilian slavery case was brought to the Inter-American 
Commission on Human Rights in 1995 (case Jose Pereira 1994-2003). The case resulted in the creation of a strong network of international and national political actors and advocates who advanced Brazilian anti-slavery laws and created the Pact for the Eradication of Slave Labour (ILO n.d), a multi-stakeholder initiative which aims to strengthen business response to modern slavery in their supply chains (Ferrera 2017, Susuki 2017).

In the United Kingdom, pressure from abolitionists in the 18th century resulted in the government establishing anti-slavery laws to abolish the slave trade, and the eventual abolition of slavery. Slave uprisings in some of the Caribbean French and English colonies, starting in Haiti and reaching Jamaica, in the 18th and 19th centuries, were events that called the attention of the European empires (Welsh 2009).

Modern slavery has also been addressed by intergovernmental organisations and international treaties, although not in a harmonised or consistent manner. Brazilian and UK anti-slavery laws rely on a different legal basis. Brazil has its judicial framework supported by civil law while the United Kingdom has common law. Hence, recommendations, such as international certifications, internal codes of conduct, and audit reports, are soft law and are scarcely considered in a country where the state's binding laws prevail.

\section{The legal concepts of slavery}

Concepts such as 'adverse incorporation' (Phillips \& Sakamoto 2012), 'unacceptable forms of work' (Fudge \& McCann 2017), and 'disposable people' (Bales 2012) are used to interpret forms of slavery in the age of globalisation and to widen the historical concept of slavery. Slavery was first legally defined in international law by the League of Nations 1926 Slavery Convention. Article 1(1) defines slavery as 'the status or condition of a person over whom any or all of the powers attaching to the right of ownership are exercised'. The League of Nations Convention also distinguished forced labour, stipulating that 'forced labour may only be exacted for public purposes' and requiring state parties 'to prevent compulsory or forced labour from developing into conditions analogous to slavery'.

The UN Supplementary Convention on the Abolition of Slavery, the Slave Trade and Institutions and Practices Similar to Slavery of 1956 (the 'Supplementary Convention' (ILO 1956)) went further than the 1926 Convention. It obliged state parties to abolish debt-bondage, serfdom, forced marriage, and child labour, in addition to slavery (Weissbrodt 2002).

To clarify the definition of slavery in international law the Bellagio-Harvard Guidelines on the legal parameters of slavery (2012) recognise the importance of establishing whether there has been an exercise of powers attaching to the right of 
ownership to determine slavery. The guidelines state that:

The manner to proceed is by making reference to that substance and not simply to the form, and first ask whether there has been an exercise of the powers attaching to the right of ownership. If so, then the more serious offence of slavery is present.

The Brazilian definition of 'slave labour' is particularly relevant, as it includes uniquely 'degrading conditions of work' as a sufficient defining criterion which is different from the International Labour Organization (ILO) definition where a forced labour situation is determined by the nature of the relationship between a person and an 'employer, and not by the type of activity performed, however hard or hazardous the conditions of work may be' (ILO 2009).

\section{The anti-slavery law in Brazil}

In 1940, slave labour was included in the Brazilian Penal Code, adopting the definition of the League of Nations against actions of 'the reduction of a person to a condition analogous to that of a slave.' Later, the amended Article 149 of the Brazilian Penal Code of 2003 defined the 'condition analogous to that of a slave' either by 'subjecting $\mathrm{him} / \mathrm{her}$ to forced labour or debilitating workdays; by subjecting him/her to degrading working conditions; or by restricting, by any means, his or her movement by reason of debt'. The National Coordination of Eradication of Slave Labour (Coordenadoria Nacional de Erradicação do Trabalho Escravo, CONAETE) established Guidelines on Slave Labour, which further suggest how the Article 149 of the Criminal Code is to be interpreted for civil prosecution in the labour courts (Scott et al. 2017). The guidelines established detailed definitions for a debilitating workday and degrading conditions which are used by Brazilian labour inspectors.

Scott et al. (2017) highlight the inspectors' crucial role in detecting adverse conditions of work and establishing that such conditions have been imposed in circumstances that constitute a legally relevant form of exploitation. In the current discourse on slavery prevention in Brazil, the sufficient resourcing of the labour inspectorate has become a key area of concern.

The labour inspectors are a crucial component of the supply-chain response and resilience against modern slavery. Although companies are increasingly expected to work against modern slavery in their supply chains, companies also rely on the presence and availability of a functioning state law enforcement infrastructure as part of their own response mechanisms. 


\section{The Dirty List and the joint liability principle}

The Dirty List (Lista Suja) was created in 2003 and until recently was published by the Brazilian Ministry of Labour and Employment, now part of the Treasury. It regulates access to information and enables the identification of modern slavery offenders. Public banks, governmental bodies, and businesses use the Dirty List as a reference document for commercial decisions, including access to loans and eligibility to bid for contracts or to become a supplier.

Many procurement departments of private businesses systemically consult the Dirty List. Companies and farm owners are initially placed on the list after a completed finding (and after an administrative appeal of the finding) of conditions analogous to slavery has been submitted. This is an administrative process that can take up to two years after the name of the employer has been published.

The Dirty List is also used as a 'naming and shaming' instrument. Scott et al. (2017) review the case of the construction sector in Brazil between 2013 and 2016. After several times having its name in the newspapers and in the official list as a violator of the law, the Civil Construction Association, representing the interests of the company MRV Engenharia e Participações, responded with a case to the Supreme Federal Tribunal charging that the Dirty List was itself unconstitutional. The case succeeded in obtaining the suspension of the official publication of the list, in part on the grounds that stigmatisation of this kind was a violation of due process. As a result, the Labour Ministry stopped updating the list until 2016 when another Supreme Court decision authorised the list to be published again.

Nevertheless, Brazil is facing setbacks and the 2018 Labour Law Reform broadened the concept of subcontracting, including subcontracting related to the core business of the outsourcing business. The relaxing of subcontracting affects two essential tools in establishing supply-chain accountability: economic dependency and structured subordination.

Economic dependency is demonstrated when all of a supplier's financial earnings come from a particular organisation. To establish structured subordination, one must establish that the worker is 'inserted in the dynamics of the leading company or final taker', which means that the worker is affected by the buyer's commercial strategy and decisions indirectly without the need to find purchase orders or other formal business procedures.

The combination of both tools has led to a broader concept of 'employee', including any worker who is defined as 'inserted in the dynamics of the taker of the service economically dependent to the purchaser company'. Employers have a duty of care for workers and are accountable for their social and labour rights. The legality of 
subcontracting affects courts' decisions if in the contracts there are clauses excluding companies from the responsibility of those rights in cases of harm occurring at work.

However, there are other elements and principles, such as objective responsibility and joint liability, derived from Brazilian environmental laws. Those who directly or indirectly benefit from economic activity that results in damage to the environment are accountable for the crime and/or violation. Hence, in combination with the Brazilian Constitution, the concept of environment is extended to the workplace.

Consequently, cases of violations of the labour laws harm the healthiness of the workplace, affecting workers' mental and physical health. The objective responsibility is independent from the work relationship between employer and worker and extends accountability to all legal entities in the supply chain. Joint liability effectively meets the public interest of safeguarding the full reparation of damages to injured workers and society. The beneficiaries of the forced labour and slavery conditions are objectively and jointly responsible for the reparation.

The commercial implications and costs of modern slavery being found in a company's supply chain are therefore much more severe in the Brazilian business context than they may be for UK companies with which they conduct business. In addition, the wider definition of modern slavery reduces the threshold for a case of modern slavery to be legally established in a company's supply chain.

\section{RESEARCH APPROACH AND CONTEXT}

This research is based on a review of annual MSA statements of UK companies importing Brazilian beef and timber and interviews with key supply-chain actors and stakeholders in Brazil and the United Kingdom in 2018. Participants included representatives of exporting businesses from the beef and timber sectors, trade associations, importers, labour inspectors, human rights and modern slavery non-governmental organisations (NGOs), government officials, certification bodies, and development finance. We also brought these supply-chain actors and stakeholders together in three workshops in Brazil and the United Kingdom and also discussed the sustainability approaches of market-leading Brazilian companies from the timber and the beef sector businesses at their facilities. Their views have fed into the scope and discussions of the following sections.

At an operational level, beef and timber supply chains were affected by many more laws and regulations than just the anti-slavery laws and we will outline the key legal and regulatory influences in the following sections to provide a clearer understanding of the industries' wider governance and also illustrate them along their supply chains in Figures 1 and 2. 
In the beef and timber sectors, sustainability initiatives have focussed primarily on tackling deforestation. Brazil began the process of developing its own Forest Stewardship Council (FSC) standards in 1997, with the first forest management standard that was recognised by FSC International in 2002. In 2009, the international NGO Greenpeace published its landmark report 'Slaughtering the Amazon' that brought worldwide attention to the environmental damage and labour exploitation throughout Amazonia caused by deforestation for cattle ranching (Greenpeace 2009). The link between deforestation and slave labour has more recently been highlighted more widely (Bales 2016). Initial interventions as a result of activists' and legal pressure resulted in the then 'Big 4' Brazilian meat processors signing what came to be known as the G4 Cattle Agreement: an undertaking to block supplies when government inspections found them guilty of using slave labour.

Although both sectors started from the point of protecting the Amazon rainforest, the mechanisms expanded and developed and for the beef sector additional aspects of animal welfare and food quality are also crucial from a commercial viewpoint. In the following sections, the situation in the beef and timber sectors is explained in more detail.

\section{Beef}

Beef consumption in the United Kingdom is relatively stable, with between a quarter and a fifth of consumed product imported. The volume of imported processed beef

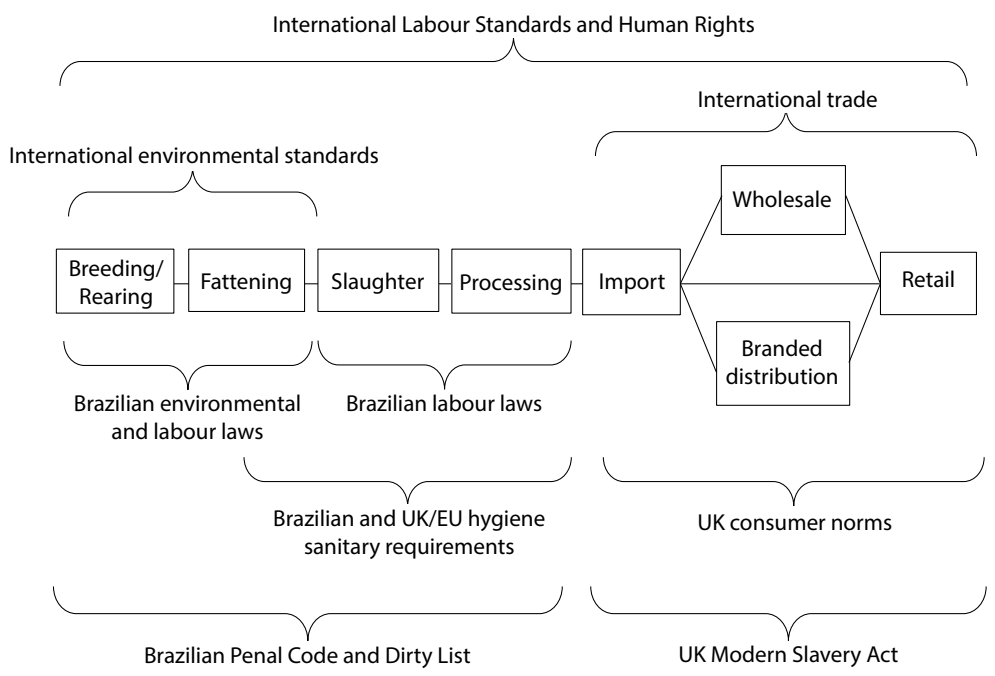

Figure 1. The Brazilian-UK corned beef supply chain and its legal framework. 
has risen over the past two years, with Brazil by far the most important source of production, accounting for 89 per cent of UK supply (Agriculture and Horticulture Development Board 2017). The single most important processed beef product imported to the United Kingdom from Brazil is corned beef.

Regulation (EC) no. 854/2004 contains rules for official controls on products of animal origin intended for human consumption (EU 2004). It specifies the requirements (auditing standards, etc.) for third-party country authorities to approve food-producing establishments for EU export. Although the European Trade Control and Expert System (TRACES) publishes lists of approved meat-producing establishments, it does not cover labour rights. Voluntary global initiatives, such as the Sustainable Agricultural Network standard (SAN) developed for the cattle sector did not have much uptake (Alves-Pinto et al. 2013, 2015, Cameron 2016, Gueneau 2018, Maguire-Rajpaul et al. 2016, Newton et al. 2015).

\section{Sanitary requirements and the beef supply chain}

Transport controls and sanitary certifications in Brazil are regulated by the Guide on Animal Transport (Guia de Transporte do Animal, GTA). Although identification mechanisms vary, this is obligatory for all beef producers. The GTA includes information relating to the sanitary conditions of the animal and its destination at the point that the animal reaches the slaughterhouse. The voluntary scheme known as the Bovine and Bubaline Production Chain Traceability Service (Servico de Rastreabilidade da Cadeia Productiva de Bovinos, SISBOV) that operates where the final market requires producers to identify traceability to the individual animal is not required for corned beef. Neither scheme covers labour conditions in the production chain through which the animals pass.

In Brazil, the administrative requirements involving animal products and exports involve three main procedures: the traceability of the products, the registration of the production units, and sanitary and environmental inspections. Initially, there were different stakeholders and institutions involved in the various procedures, but in the last few decades there has been an effort to concentrate procedures in the Ministry of Agriculture and its subordinate agencies.

The increasing rigidity and specificity of export requirements for animal products are contributing to a concentration of authorised export establishments in the hands of a few larger producers with the capabilities to satisfy these requirements.

Currently, three aspects are affecting the beef supply chain concerning the implementation of modern slavery eradication measures: the overlap of institutions' competence, the omission of action given the functional approach of inspections, and confidentiality of traceability documents. In the first case, the overlap provokes a reaction of the private sector claiming an excess of requirements. The second aspect 
supports the lack of action by governmental agencies when the different institutions based on a functionality approach do not act when confronted with breaches of laws out of their competence. The failure to act in situations of forced labour or degrading conditions is thus legitimated, once there is no obligation to report other types of violations out of the institutions' attributions. If forced labour is found in a specific supply chain during an inspection of a different scope, this violation does not need to be reported. In the third, the confidentiality of the GTA is seen as an obstacle to transparency in the beef supply chain affecting the traceability of the animal.

The non-compliance with sanitary, environmental, and labour laws have their individual sanctions regimes. The labour law sanctions are of little value, especially when compared to the companies' income (Lage \& Cardoso 2005). Non-compliance with sanitary requirements is punished with the suspension of international certification for export and can temporarily shut down operations, which results in a substantial financial loss for a large exporter. The sanctions for environmental law violations use civil, administrative, and even criminal punishments, with considerable effects on the business and its supply chain.

The sanitary requirements can affect different markets at the domestic, international, and regional levels. All established manufacturers of animal products in the country must have authorisation to operate given by one of the Secretaries of Sanitation Inspection of the Ministry of Agriculture. However, export establishments must register at the Secretary of Federal Sanitation Inspection. After registration, there are, in general, three levels of sanitary requirements to attain the final authorisation. The first level refers to manufacturers focussed on the domestic market, and the two others are related to establishments that aim to be included on lists of exporters of animal products. The first level of producers should prove their ability to comply with domestic sanitation laws. The second type of establishment needs to commit to Brazilian laws in addition to general international requirements, such as the WTO (World Trade Organization) Agreement on Sanitary and Phytosanitary Measures (SPS). At the third and last level are producers able to commit to the specific requirements of different import countries and trade blocs besides Brazilian laws. These three levels of sanitary requirements result in different certification schemes for export.

Before inclusion in the lists of exporters, a term of compliance with the sanitation requirements of specific countries and/or trade areas needs to be signed by the competent manager of the production unit. One example of specific requirements on exports is registration at the EU Commission of production units' exporters to the European countries. To obtain this registration, the establishment must prove its conformity with specific patterns following EU laws, which are different from those stated in the WTO-SPS Agreement. 
Traceability of animals is the main reason for the rigid requirements imposed by regional markets. Since 2006, two critical laws to follow sanitary and phytosanitary requirements were released, focussing on the importance of animal and vegetable traceability and the responsibilities of members of the supply chains. The first provides the broader elements and obligations regarding transport controls and sanitary certifications of the products and the latter, in force since 2009, made traceability compulsory, so regulating the GTA. Hence, the traceability of animals is an obligation for all producers in the beef supply chain.

The GTA includes the sanitary conditions of the animal, its destination and its death. It is one of the most influential tools for tracing the origin of the product until the animal enters the slaughtering farms or slaughterhouses. The GTA should accompany the animal during its transportation to the different farms, beginning at the birth farms ('fazenda de cria') through the fattening farm ('fazenda de engorda'), and the confining farm ('fazenda de confinamento'), ending at the slaughtering farm ('fazenda de abate'). Stakeholders in the beef supply chain stressed proposals to include the status of social standard conditions in the GTAs. The GTAs have been made official and consider confidential information affecting the whole process of traceability.

Nevertheless, the Bovine and Bubaline Production Chain Traceability Service (Serviço de Rastreabilidade da Cadeia Produtiva de Bovinos e Bubalinos, SISBOV) launched in 2006, is directed towards producers interested in selling to markets that require an individual identification of the animal, such as registered slaughterhouses. Although by law adherence to SISBOV is voluntary, in practice, it must be adopted in the formal beef market.

The SISBOV certification means higher costs considering that the producer has to contract one of the certification firms listed in the Ministry of Agriculture system. This results in two types of markets: one that purchases the animals originating from unregistered units (informal), and a second market that will only accept animals originating from units registered at SISBOV.

\section{Timber}

In 2017, Brazilian exports to the United Kingdom accounted for 3.9 per cent (or approximately $£ 7.37$ million) of Brazil's total wood exports (Anon 2018), covering a variety of timber products: mouldings, plywood, furniture, joinery, pulp, paper, and sawn wood (TFT 2013). Timber exports to the United Kingdom are governed by the EU Timber Regulation (EU/995/2010) (EU 2010, Brack \& Saunders 2017, TFT 2013). The EU Timber Regulation requires the first operator which brings timber into the EU market to exercise 'due diligence' to ensure that the risk of illegally harvested 


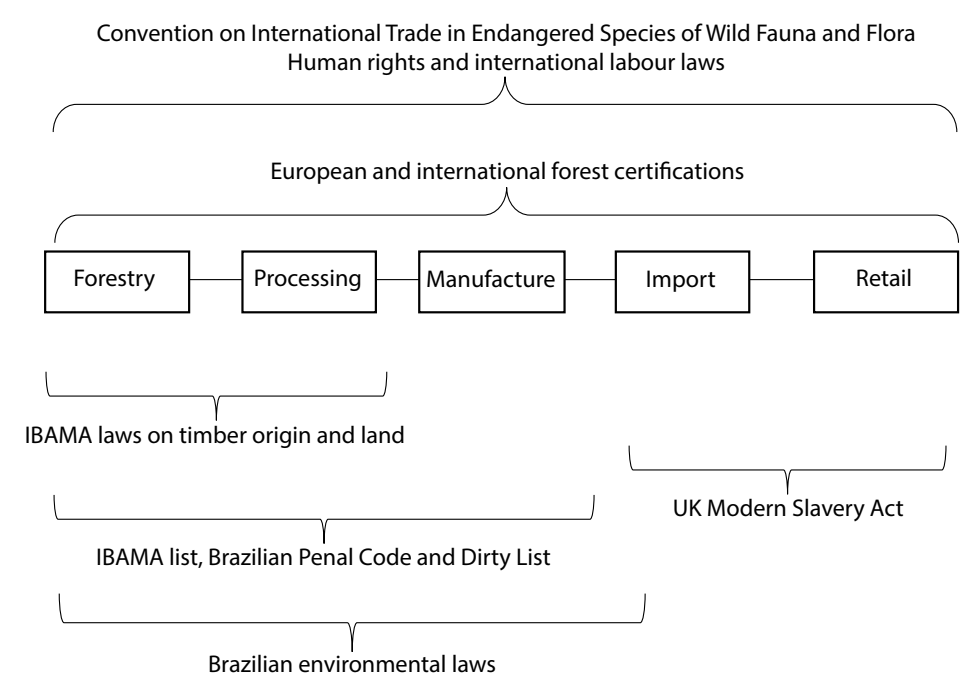

Figure 2. The Brazilian-UK plywood supply chain and its legal framework.

timber and timber products is minimised. It does not currently include any requirements that relate specifically to labour conditions.

\section{Traceability and the timber supply chain}

The new Forest Code 2012 requires that all private rural farms have part of the land destined for native forest conservation. Depending on the biome, this rate varies from 20 per cent to 80 per cent of the total area. For instance in the Amazon biome, 80 per cent of the land needs to be for conservation purposes, leaving the owner 20 per cent of the area for economic activities. Considering the dimensions of the farms in the Amazon region this can still be a large area. Recognition of the impact of forest conservation on climate change and the contribution of the Amazonian biodiversity worldwide put pressure on the Brazilian environmental state agencies, resulting in one of the most rigorous systems of surveillance and monitoring of timber in the world (Chiavari \& Mendes 2017).

Brazil has administrative and legislative powers for forestry at the national and state levels. These include a computer-based Declarations of Origin (DOF) system to control trade and transportation of timber and other forest products (TFT 2013). This system enables products to be traced back from the point of export, through the various stages of processing to its forest source. Nevertheless, illegal trade in timber is still reported in remote areas and the Rural Environmental Registry (Cadastro Ambiental Rural, CAR) operates an electronic register of georeferenced information 
for rural property in the whole country. It includes property perimeters, location of permanent preservation areas, legal reserves, and areas of agricultural productions. The CAR is not part of the land property rights or fiscal regimes in Brazil, which means it does not control landownership, but controls and monitors only deforestation.

The timber supply chain has no sanitation requirements. However, it has strict procedures for the export of products and sub-products of wood, based on Annexes I, II, and III of the Convention on the International Trade in Endangered Species of Wild Flora and Fauna (Convencão sobre o Comércio Internacional das Especies da Flora e Fauna Selvagens em Perigo de Extinção, CITES). The law also lists types of wood species that may be exported only when they derive from planted forests or sustainable management forest plans. In these cases, the wood must be accompanied by a DOF, which will prove its origin at the export stage.

The Ministry of the Environment through the National System of the Environment (Sistema Nacional do Meio Ambiente, SISNAMA) holds the competency to create the administrative rules to supervise and control the production, sales, and export of timber in Brazil with the support of the National Environmental Council (Conselho Nacional do Meio Ambiente, CONAMA). The Brazilian Institute of Environment and Renewable Natural Resources (Instituto Brasileiro do Meio Ambiente e dos Recursos Naturais Renováveis, IBAMA) conducts the inspections.

After mapping the beef and timber supply chains and understanding the legal and regulatory frameworks they are operating in, the next section will add their supply-chain characteristics.

\section{SUPPLY-CHAIN CHARACTERISTICS OF THE BRAZILIAN-UK BEEF AND TIMBER SUPPLY CHAINS}

By contrasting the two sectors, their supply chains and the legal frameworks around them, we identified several themes that were repeatedly raised by our research participants. They are summarised in Table 1. As industry practitioners from these sectors pointed out, the export market is smaller than the domestic market for the sectors and the United Kingdom has a relatively small share of that export market, with significantly higher compliance requirements than larger alternative markets. Participants also raised the intersectionality of modern slavery occurrences with other sustainability issues, such as land theft, corruption, and deforestation. 
Table 1. Supply-chain characteristics for the Brazilian beef and timber supply chains.

\begin{tabular}{|c|c|c|}
\hline Supply-chain dimension & Beef & Timber \\
\hline \multirow[t]{2}{*}{ Global export markets } & $\begin{array}{l}\text { Different markets buying } \\
\text { different cuts }\end{array}$ & Product the same for all markets \\
\hline & $\begin{array}{l}\text { Variety of requirements and } \\
\text { standards (for example, } \\
\text { religious, traceability, food } \\
\text { hygiene) }\end{array}$ & $\begin{array}{l}\text { Multinational companies } \\
\text { require sustainability } \\
\text { certification for all markets }\end{array}$ \\
\hline \multirow[t]{3}{*}{ Buyer-supplier relationship } & Short-term & Long-term \\
\hline & Daily spot buying & $\begin{array}{l}7-12 \text { years, purchase price a } \\
\text { combination of agreed-today } \\
\text { and spot price at harvest }\end{array}$ \\
\hline & & $\begin{array}{l}\text { Payment in instalments over the } \\
\text { growth period }\end{array}$ \\
\hline $\begin{array}{l}\text { Supplier's ability to sell to } \\
\text { someone else }\end{array}$ & $\begin{array}{l}\text { Easy, as competitors operate } \\
\text { in the same areas }\end{array}$ & $\begin{array}{l}\text { Limited, as transportation costs } \\
\text { will reduce profitability and } \\
\text { competitors have similar } \\
\text { requirements }\end{array}$ \\
\hline Supply alternatives & Entirely external supplier base & $\begin{array}{l}\text { Own forests plus sourcing from } \\
\text { external suppliers }\end{array}$ \\
\hline Number of suppliers & Up to 70,000 & Up to 2,000 \\
\hline
\end{tabular}

As Table 1 highlights, the timber and beef markets have very different supply-chain characteristics. In addition, the market access to Europe for Brazilian beef and timber also follows different product expectations. Fresh Brazilian beef for the European market is sold under the 'Hilton Quota' system, which requires that operations be performed to enhanced sanitary standards. The same is not true for processed corned beef, where processors are not even required to adhere to Brazil's national SISBOV standard. Whereas timber civil certifications, such as Forest Stewardship Council (FSC) or Programme for the Endorsement of Forest Certification (PEFC), have become 'order qualifiers' for large, multinational companies.

Buyer-supplier relationships are also dramatically different, with arm's-length spot-market relationships being the norm in the beef sector and long-term, collaborative relationships characterising the purchase of timber. Timber is a 90 per cent contract market, with only 10 per cent of raw timber purchased on the spot market. The beef industry is the opposite - with only 10 per cent of cattle bought using future contracts and 90 per cent purchased on the spot market. 
In the following sections we briefly summarise the MSA statements of beef and timber sector companies covered by the MSA and then portray how two marketleading companies from the beef and timber sectors approach the challenge of combatting slavery in their upstream supply chains.

\section{Beef}

In the annual statements of UK retailers of corned beef, slavery is frequently covered under the more general rubric of human rights. These companies list a raft of policies, principles, standards, statements, handbooks, and codes of conduct and practice. There is little evidence of these instruments cascading upstream via the big Brazilian processor/exporters to the plethora of their supplying farms. Furthermore, while many UK retailers make mention of anti-slavery supply-chain initiatives, Brazil is mentioned as a high-risk location by only one retailer, and beef is not identified as a category of interest. One branded distributor does identify Brazil as one of six priority hot spots and indicates its intention to conduct further review and risk assessment, beyond its first-tier suppliers, although no further detail is given.

\section{Case study: JBS}

In response to the United Kingdom's Modern Slavery Act, JBS described to us how it has leveraged a business-non-business partnership developed with the Brazilian anti-slavery NGO, InPACTO (Instituto Pacto Nacional pela Erradicação do Trabalho Escravo), to develop a social vulnerability risk-monitoring tool. The project is intended to increase possibilities for managing the risk and prevention of slave labour across JBS supply chains by identifying regions vulnerable to slave labour and mapping 'hot spot' areas. A risk-detection system has been developed that relies on the triangulation of data and indicators from both JBS and InPACTO; and which the partners intend shall be made available to all companies in the Brazilian meat-processing industry. As JBS’s Sustainability Manager explained to us:

InPACTO was critical. They bring good guys to work with [the] JBS team and they had the power to make this a great tool for the rest of [the] Brazilian companies.

This initiative aims to improve risk monitoring and uses existing social and environmental risk systems developed for the legal Amazon under Brazil's 'G4' cattle agreement which committed the major Brazilian meatpackers to exclude source farms of any of its 70,000 suppliers involved in any deforestation, slave labour, or the invasion of indigenous lands and environmentally protected areas. As part of this commitment, JBS's existing buying procedures are already subject to third-party audit that monitors each of the signatories' compliance with the blocking of 'dirty-listed' suppliers. 
For the new tool, JBS provides ten years of geographical and territorial risk data that have been combined with socio-economic and demographic data from InPACTO. Correlation of known cases of slave labour in the legal Amazon with these two data sources has been used to identify five categorical groups. Each category is divided into five different risk levels. From these data, a map is produced that indicates the risk at municipal, and - for JBS's own use - finer, granularity. JBS intends to use this map to overlay the locations of its twenty-six processing units and the sites of its suppliers' farms. This will enable it to analyse the percentage of its suppliers' farms in each risk category. Its intention is to target further investigations: for example, social audits, at a percentage of farms in each risk category, informed by the proportion of cattle that the farm supplies to JBS and the export markets which each respective buying unit serves.

In response to the United Kingdom's modern slavery legislation, this case demonstrates how one major buyer in the cattle industry has begun to forge a relationship with an influential Brazilian NGO to develop risk-detection capabilities across the sector. This moves supply practices in the sector forward beyond the boycott of dirtylisted suppliers. While the initiative is still in the early stages, the spot-market characteristics and number of suppliers in this sector necessitate a risk-based approach to detection and remediation.

\section{Timber}

A second case describes how alternative solutions have been developed in one timber supply chain, where it has proved possible to develop closer relationships beyond immediate suppliers.

In their annual modern slavery statements, UK timber companies describe a reliance on certification to ensure that their supply chains are slavery free. Brazilian timber exporters have turned to civil standards such as the Forest and Stewardship Council (FSC) forest certification and Programme for the Endorsement of Forest Certification (PEFC) to demonstrate compliance with laws and norms associated with environmental and social conditions, including those related to labour abuses (Araujo et al. 2009, Pinto \& McDermott 2013). Principle 2 of the FSC's Forest Certification standard requires that organisations maintain or enhance the social and economic well-being of workers and includes the requirement to uphold the principles and rights at work defined in the International Labour Organization's Declaration on Fundamental Principles and Rights at Work (ILO 1998) (Forest Stewardship Council 2015). 


\section{Case study: Klabin}

Klabin is Brazil's largest paper producer and exporter, with seventeen units throughout Brazil. In 1996, it became the first company in Brazil to achieve FSC certification and it has also been instrumental in the development of FSC Brazil's Small and Low Intensity Managed Forest, or SLIMF, standard.

In 2016, it opened a new unit in Paraná in the South of Brazil. According to International Finance Corporation rules, it is required to specify performance standards for working and labour conditions, including the requirement to recognise risks in its primary supply chains. Timber for the unit comes from Paraná and nearby states: Santa Catarina and São Paulo. Between 20 and 30 per cent of this timber is supplied by smallholders. Supply-chain operations have changed. Even smallholders' operations have become more mechanised. Although still present in some parts of the timber industry, Klabin no longer purchases its timber supplies from smallholders who use manual labour. This avoids the risks associated with poor health and safety practices and the potential for exploitative working conditions, such as forced labour.

Though not a direct result of the MSA, the initiative Klabin managers described to us involved its supply-chain level development of local smallholders. Built upon the development of the SLIMF standard, its intention was to drive FSC certification across the sector through consultancy support and the promise of a price premium for FSC-certified timber. What is particularly interesting about this initiative is that Klabin worked not only with its own 2,000 suppliers, but also with other smallholders in the surrounding area. As Klabin's Environment and Forest Certification manager explained:

They [smallholders] are convinced it's good for them and good for the world. If you don't have this kind of stamp, in five to ten years it will be difficult to sell. More so in Europe, less in Brazil, but it's going to be the standard.

Certification was initially carried out by a Klabin team, although this was eventually outsourced to a specialist consultancy. Despite the SLIMF standard being less demanding than the FSC forest management and chain of custody standards to which Klabin adhered, SLIMF certification required smallholders to deliver improvements in their working practices - including labour conditions. As such, certification audits provided an opportunity for learning. Should non-conformances be found, there was no need to block smallholders-since they were not suppliers-rather the issues could be seen as an opportunity for dialogue and corrective action.

In the timber sector, then, where there are fewer suppliers and longer-term contracts and where certification has become the norm, this timber processor had extended certification - with its in-built emphasis on improved labour conditions - to develop potential suppliers close to its operations. It is important, however, to note 
the interaction between certification and changing national laws. Standards are audited to ensure that certification holders comply with national legislation. Where there are regressive attempts to soften slavery law - as is currently the case in Brazilthe potency of soft law certification as a governance mode is also diminished.

\section{DISCUSSION AND CONCLUSIONS}

Many factors affect the modern slavery risk in a supply chain. Although the United Kingdom's Modern Slavery Act undoubtedly had an effect on raising very difficult conversations between companies in Brazil-UK supply chains, implementation depends strongly on enablers that are in place due to other regulation and legislation, marketsector characteristics, and supply-chain design. The effect on other regulatory and legislative frameworks usually does not cover the supply chain from end to end. Whereas businesses are often expected to understand their full supply chain, it is clear that regulations and legislation often covers only individual parts of the supply chain.

In some areas, modern slavery can only be eradicated effectively with a major change in supply-chain practices and structures. In the current Brazil-UK beef supply chain, the commercially dominant use of spot-market buying creates dynamics in the market and supply network that prevents anything more than gradual moves towards improvement. Further analysis is needed here into how the current short-termism in buyer-supplier relationships that has grown historically can be overcome by new commercial structures. Supply chains develop in ways that eventually lead to the most commercially advantageous solution within the framework in which they operate, and it must therefore be changed further to direct the sector into a commercial preference for modern slavery prevention.

In our research it became clear that the ambition to have companies police their own supply chains is limited and simultaneously requires functioning state institutions and law enforcement and cannot replace them. The logistical challenges in covering Brazil's agricultural sector are even more difficult to master for companies than for state institutions. Furthermore, it is a concern that business decisions do not require any checks and balances, and the blacklisting of suppliers gives companies significant power over suppliers. Providing companies with such powers is not only worrying from a law perspective, but also as companies are neither equipped to nor want to undertake these policing roles.

At the moment, slavery prevention in the timber and beef sectors are additional costs that other-less scrupulous - suppliers do not incur. In the timber sector, this cost is an entry ticket that is required for the global export markets by the EU Timber Regulation and the requirements of multinational buyers. 
Understanding the variations between the supply chains in Brazilian-UK timber and beef supply chains highlights the need for sector-specific solutions and the need for supply-chain collaboration and exchange between the supply-chain actors involved.

\section{REFERENCES}

Agriculture and Horticulture Development Board (2017), 'UK Yearbook 2017 cattle'. http://beefandlamb.ahdb.org.uk/wp-content/uploads/2017/07/UK-Yearbook-2017-cattle.pdf [accessed 21 May 2018].

Alves-Pinto, H. N., Newton, P. \& Pinto, L. F. G. (2013), 'Certifying Sustainability: Opportunities and Challenges for the Cattle Supply Chain in Brazil', CGIAR Working Paper No. 57, CGIAR Research Program on Climate Change, Agriculture and Food Security (CCAFS), Copenhagen. http://www.ccafs.cgiar.org

Alves-Pinto, H. N., Newton, P. \& Pinto, L. F. G. (2015), 'Reducing Deforestation and Enhancing Sustainability in Commodity Supply Chains: Interactions Between Governance Interventions and Cattle Certification in Brazil', Tropical Conservation Science, 8(4): 1053-79. https://doi.org/10.1177/194008291500800414

Anon (2018), 'Brazil'. http://www.timbertradeportal.com/countries/brazil [accessed 29 May 2018].

Araujo, M., Kant, S. \& Couto, L. (2009), 'Why Brazilian Companies Are Certifying Their Forests?”, Forest Policy and Economics, 11(8): 579-85. https://doi.org/10.1016/j.forpol.2009.07.008

Bales, K. (2012), Disposable People: New Slavery in the Global Economy (Berkeley, CA, University of California Press).

Bales, K. (2016), Blood and Earth: Modern Slavery, Ecocide, and the Secret to Saving the World (New York, Spiegel and Grau).

Brack, D. \& Saunders, J. (2017), 'The UK Modern Slavery Act and EU Timber Regulation: Synergies and divergence'. http://www.forest-trends.org/documents/files/doc_5709.pdf [accessed 13 February 2018].

Cameron, B. (2016), 'The Drive to Protect Forests: Introducing Sustainable Cattle Certification in Brazil, 2009-2016', Global Challenges Certification Innovations for Successful Societies.

https://successfulsocieties.princeton.edu/publications/drive-protect-forests-introducing-sustainablecattle-certification-brazil-2009-2016 [accessed 19 April 2018].

Chesney, T., Evans, K., Gold, S. \& Trautrims, A. (2019), 'Understanding Labour Exploitation in the Spanish Agricultural Sector Using an Agent Based Approach', Journal of Cleaner Production, 214: 696-704. https://doi.org/10.1016/j.jclepro.2018.12.282

Chiavari J., \& Mendes, C. (2017), 'Legislação Florestal e de Uso da Terra. Uma Comparação Internacional', Climate Policy Initiative (CPI) and Núcleo de Avaliação de Políticas Climáticas da PUC-Rio (NAPC/PUC-Rio).

Choi-Fitzpatrick, A. (2015), 'From Rescue to Representation: A Human Rights Approach to the Contemporary Anti-Slavery Movement', Journal of Human Rights, 14(4): 486-503. https://doi.org/10.1080/14754835.2015.1032222

Crane, A. (2013), 'Modern Slavery as a Management Practice: Exploring the Conditions and Capabilities for Human Exploitation', Academy of Management Review, 38(1): 49-69. https://doi.org/10.5465/amr.2011.0145

Emberson, C. \& Trautrims, A. (2019), 'Public Procurement and Modern Slavery Risks in the English Adult Social Care Sector', in O. Martin-Ortega \& C. Methven O’Brien (eds), Public Procurement and Human Rights Opportunities, Risks and Dilemmas for the State as Buyer (Cheltenham, Glos, Edward Elgar). 
EU (2004), Regulation (EC) No 854/2004 Of The European Parliament and of the Council of 29 April 2004: Laying Down Specific Rules for the Organisation of Official Controls on Products of Animal Origin Intended for Human Consumption. https://eur-lex.europa.eu/legal-content/EN/TXT/?uri=CELEX\%3A32004R0854

EU (2010), Regulation (EU) No 995/2010 of the European Parliament and of the Council of 20 October 2010 Laying Down the Obligations of Operators Who Place Timber and Timber Products on the Market Text With EEA Relevance. https://eur-lex.europa.eu/legal-content/EN/TXT/?uri=CELEX\%3A32010R0995

Ferrera, N. O. (2017), 'Trabalho Análogo ao de Escravo. Debates em Torno de um Conceito Transnacional', in Ricardo Rezende Figueira, Adoria Antunes Prado \& Edna Galvão (eds), Trabalho Escravo Contemporâneo. Estudo sobre Ações e Atores (Rio de Janeiro, Editora Mauad).

Forest Stewardship Council (2015), 'FSC International Standard: FSC Principles and Criteria for Forest Stewardship', FSC-STD-01-001 V5-2 EN.

https://ic.fsc.org/file-download.fsc-principles-and-criteria-for-forest-stewardship-fsc-std-01-001v5-2-en-web-version.a-216.pdf [accessed 22 January 2019].

Fudge, J. \& MacCann, D. (2017), 'Unacceptable Forms of Work: A Multidimensional Model', International Labour Review, 156(2): 147-84. https://doi.org/10.1111/ilr.12002

Gold, S., Trautrims, A. \& Trodd, Z. (2015), 'Modern Slavery Challenges to Supply Chain Management', Supply Chain Management: An International Journal, 20(5): 485-94. https://doi.org/10.1108/SCM-02-2015-0046

Gomes, A. C. (2008), 'Trabalho Análogo ao de Escravo: construindo um problema', História Oral, 11 (1-2), Rio de Janeiro.

Greenpeace (2009), 'Slaughtering the Amazon'.

https://www.greenpeace.org/usa/research/slaughtering-the-amazon/ [accessed 15 March 2019].

Gueneau, S. (2018), 'Neoliberalism and the Emergence of Private Sustainability Initiatives: The Case of the Brazilian Cattle Value Chain', Business Strategy and the Environment, 27(2): 240-51. https://doi.org/10.1002/bse.2013

Guo, R., Lee, H. L. \& Swinney, R. (2015), 'Responsible Sourcing in Supply Chains', Management Science, 62(9): 2722-44. https://doi.org/10.1287/mnsc.2015.2256

Hofmann, H., Schleper, M. C. \& Blome, C. (2018), 'Conflict Minerals and Supply Chain Due Diligence: An Exploratory Study of Multi-tier Supply Chain', Journal of Business Ethics, 147(1): 115-41. https://doi.org/10.1007/s10551-015-2963-z

ILO (1956), Supplementary Convention on the Abolition of Slavery, the Slave Trade, and Institutions and Practices Similar to Slavery, International Labour Organization.

http://www.un.org/en/genocideprevention/documents/atrocity-crimes/Doc.15_supplementary\% 20slaverytrade.pdf

ILO (1998), Declaration on Fundamental Principles and Rights at Work, International Labour Organization. https://www.ilo.org/declaration/thedeclaration/textdeclaration/lang--en/index.htm

ILO (2009), 'The cost of coercion', International Labour Conference, 98th session.

https://www.ilo.org/wcmsp5/groups/public/---ed_norm/---declaration/documents/publication/ wcms_106268.pdf

ILO (no date), 'Pact for the Eradication of Slave Labour', International Labour Organization. https://www.ilo.org/wcmsp5/groups/public/---dgreports/---ilo-washington/documents/genericdocument/wcms_189835.pdf

Kim, S., Wagner, S. M. \& Colicchia, C. (2019), 'The Impact of Supplier Sustainability Risk on Shareholder Value', Journal of Supply Chain Management, 55(1): 71-87. https://doi.org/10.1111/jscm.12188

Lage, T. \& Cardoso, A. (2005), 'A Inspeção do Trabalho no Brasil', DADOS-Revista de Ciências Sociais, 48(3): 451-90 (Rio de Janeiro). https://doi.org/10.1590/S0011-52582005000300001 
LeBaron, G., Lister, J. \& Dauvergne, P. (2017), 'Governing Global Supply Chain Sustainability Through the Ethical Audit Regime', Globalizations, 14(6): 958-75. https://doi.org/10.1080/14747731.2017.1304008

League of Nations (1926) Slavery Convention. https://www.ohchr.org/EN/ProfessionalInterest/Pages/SlaveryConvention.aspx

Maguire-Rajpaul, V. A., Galuchi, T. \& Alves-Pinto, H. N. (2016), 'How Brazil's Sustainable Cattle Schemes Could Beef Up to Conserve Forests and Sustainable Rural Livelihoods', CCAFS Working Paper No 148, CGIAR Research Program on Climate Change, Agriculture and Food Security (CCAFS), Copenhagen. http://www.ccafs.cgiar.org.

Modern Slavery Act 2015. (c.30) (London, The Stationery Office). http://www.legislation.gov.uk/ukpga/2015/30/contents/enacted

New, S. J. (2015), 'Modern Slavery and the Supply Chain: The Limits of Corporate Social Responsibility?' Supply Chain Management: An International Journal, 20(6): 697-707. https://doi.org/10.1108/SCM-06-2015-0201

Newton, P., Alves-Pinto, H. N. \& Pinto, L. F. G. (2015), 'Certification, Forest Conservation, and Cattle: Theories and Evidence of Change in Brazil', Conservation Letters, 8(3): 206-13. https://doi.org/10.1111/conl.12116

Phillips, N. \& Sakamoto, L. (2012), 'Global Production Networks, Chronic Poverty and "Slave Labour" in Brazil', Studies in Comparative International Development, 47: 287-315. https://doi.org/10.1007/s12116-012-9101-z

Pinto, L. F. G. \& McDermott, C. (2013), 'Equity and Forest Certification-A Case Study in Brazil', Forest Policy and Economics, 30: 23-9. https://doi.org/10.1016/j.forpol.2013.03.002

Pishchulov, G., Trautrims, A., Chesney, T., Gold, S. \& Schwab, L. (2019), 'The Voting Analytic Hierarchy Process Revisited: A Revised Method with Application to Sustainable Supplier Selection', International Journal of Production Economics, 211: 166-79. https://doi.org/10.1016/j.ijpe.2019.01.025

Scott, R. J., de Andrade Barbosa, L. A. \& Borlido Haddad, C. H. (2017), 'How Does the Law Put a Historical Analogy to Work: Defining the Imposition of a Condition Analogous to That of a Slave in Modern Brazil', Duke Journal of Constitutional Law and Public Policy, 13(1): 1-46. https://doi.org/10.2139/ssrn.3058191

Susuki, N. (2017), 'Trabalho Análogo ao de Escravo. Debates em Torno de um Conceito Transnacional', in Ricardo Rezende Figueira, Adoria Antunes Prado \& Edna Galvão (eds), Trabalho Escravo Contemporâneo. Estudo sobre Ações e Atores (Rio de Janeiro, Editora Mauad).

TFT (2013), 'Country Guide to Timber Legality: Brazil', The Forest Trust (now Earthworm). http://www.tft-earth.org/wp-content/uploads/2013/03/TTAP_Guide_to_Legality_Brazil_1.pdf [accessed 13 February 2018].

Weissbrodt, D. (2002), 'Abolishing Slavery and its Contemporary Forms', Office of the United Nations Higher Commissioner for Human Rights, UN 2002 HR/PUB/02/4.

Welch, C. (2009), 'Defining Contemporary Forms of Slavery: Updating a Venerable NGO', Human Rights Quarterly, 31(1): 70-128. https://doi.org/10.1353/hrq.0.0050

WTO (1995), The WTO Agreement on the Application of Sanitary and Phytosanitary Measures (SPS Agreement), World Trade Organization. https://www.wto.org/english/tratop_e/sps_e/spsagr_e.htm

Xiao, C., Wilhelm, M., van der Vaart, T. \& van Donk, D. P. (2019), 'Inside the Buying Firm: Exploring Responses to Paradoxical Tensions in Sustainable Supply Chain Management', Journal of Supply Chain Management, 55(1): 3-20. https://doi.org/10.1111/jscm.12170 


\section{Notes on the authors}

Silvia Marina Pinheiro worked for twenty years as an international trade lawyer in Rio de Janeiro and São Paulo with a masters degree and PhD on WTO dispute settlement mechanisms and regional trade agreements. She was a visiting researcher at the Georgetown University Law Centre in the United States and a visiting fellow at The Essex Business and Human Rights project in the United Kingdom. Currently, she teaches at The Pontifical Catholic University of Rio de Janeiro, BRICS Policy Centre, developing courses, teaching modules, and intervention projects with a focus on modern slavery eradication, aimed at marginalised populations, public servants, and enterprises. Since 2017, she has been the co-investigator in the project 'Inclusion and Formalization of Amazonian Entrepreneurs into MNC Value Chains' funded by the British Academy, under a Newton Advanced Fellowship. In Brazil, she has published two books on international trade law, reports, and articles, and she is the co-author of 'Inclusive Value Chains, Small Business and Traditional Populations: The Case of the Riverines at the Rio Negro Sustainable Development Reserve' and 'Inclusive Value Chains, Government Procurement and Opportunities for Social Enterprises in the State of the Amazon' for the ICE-Citizenship Entrepreneurial Innovation Institute- São Paulo.

Caroline Emberson works as a Research Fellow in the University of Nottingham Rights Lab's Business and Economies team, where she leads its research on slavery and public sector supply chains. Her research explores managers' perceptions of domestic and international modern slavery risk in both product and labour supply chains. She has been awarded research impact funding from the UK Economic and Social Research Council (ESRC) for her innovative work on modern slavery in adult social care and has been an invited speaker at leading national and international conferences, including those of the Prince's Responsible Business Network, UK Local Government Association and OSCE (Organization for Security and Cooperation in Europe). A summary report for practitioners of the findings of the British Academy funded research upon which this article is based may be found at: https://www. nottingham.ac.uk/research/beacons-of-excellence/rights-lab/mseu/mseu-resources/ 2019/march/emberson-tackling-slavery-in-supply-chains.pdf. caroline.emberson@nottingham.ac.uk.

Alexander Trautrims is leading the Unchained Supply project at the University of Nottingham's Rights Lab. His work focusses on the identification and eradication of modern slavery in supply chains and the effect of supply-chain structures and practices on the occurrence and prevention of modern slavery. The work of his team has covered modern slavery within a wide range of business and supply-chain areas: 
public procurement of adult social care; hand car washes in the United Kingdom; game-theoretical barriers to the diffusion of good practices and the response of business organisations to modern slavery legislation and supply-chain exposure. His research is characterised by its usefulness for implementation. Together with UK construction companies he produced the first modern slavery procurement guidelines for the sector, he is working with the OSCE on its slavery-free procurement initiative and he has trained human rights officers for the Foreign and Commonwealth Office. He introduced modern slavery as a supply-chain topic as a co-author of the first modern slavery article in a supply-chain management journal and he regularly contributes to academic and practitioner debates and publications on modern slavery in supply chains.

Alexander.Trautrims@nottingham.ac.uk

\section{Recent papers:}

Chesney, T., Evans, K., Gold, S. \& Trautrims, A. (2019), 'Understanding Labour Exploitation in the Spanish Agricultural Sector Using an Agent Based Approach', Journal of Cleaner Production, 214: 696-704. https://doi.org/10.1016/j.jclepro.2018.12.282

Emberson, C. \& Trautrims, A. (2019), 'Modern Slavery Risk Under Contracting-out of Health Services: A Case Study of Local Government Adult Social Care In England', in O. Martin-Ortega, \& C. Methven O'Brien (eds) Public Procurement and Human Rights: Risks, Opportunities and Dilemmas for the State as Buyer (Cheltenham, Glos, Edward Elgar).

Gold, S., Trautrims, A. \& Trodd, Z. (2015), 'Modern Slavery Challenges To Supply Chain Management', Supply Chain Management: An International Journal, 20(5): 485-94. https://doi.org/10.1108/SCM-02-2015-0046

To cite the article: Silvia Marina Pinheiro, Caroline Emberson and Alexander Trautrims (2019), "For the English to see" or effective change? How supply chains are shaped by laws and regulations and what that means for the exposure of modern slavery', Journal of the British Academy, 7(s1): 167-190.

DOI https://doi.org/10.5871/jba/007s1.167

This article is licensed under a

Creative Commons Attribution-NonCommercial-NoDerivs 4.0 Unported License.

Journal of the British Academy (ISSN 2052-7217) is published by

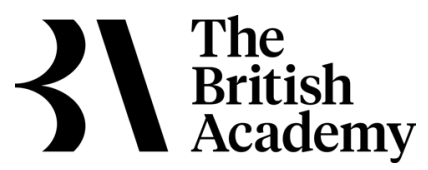

10-11 Carlton House Terrace, London, SW1Y 5AH

www.thebritishacademy.ac.uk 